\title{
Token endeavors: the significance of academic spin-offs in technology transfer and research policy in Germany
}

\author{
Andreas Knie and Martin Lengwiler
}

\begin{abstract}
Based on the principal-agent theory, this paper analyses the historical emergence of policies supporting spin-off activities since the end of the Second World War, focusing on Germany as an exemplary case study. It argues that the significance of spin-offs in research policy is not an effect of their hard-andfast number or their direct economic impacts but rather of their symbolic meaning, providing legitimacy for academic institutions and funding agencies in controversial public debates about science and technological policies. Spin-offs, like technology transfer at large, are important to the rationale and legitimacy of science and research policy.
\end{abstract}

I nterest in spin-offs from universities and research centers is booming in many regions of Europe (Konrad and Truffer, 2006; Larédo and Mustar, 2001; OECD, 2001). The topic is especially popular in Germany, where the recent high-tech initiative spearheaded by the federal government has made it a strategic objective of all research policy to foster an entrepreneurial climate in the science system. In a prominent report, the German Federal Ministry of Education and Research confirmed the importance of spin-offs for current economic and innovation policies: "The federal government is improving the conditions for start-ups and is reorganizing the financial support it offers for the founding of technology-centered enterprises in order to strengthen the dynamics for setting up ventures and financing innovation". The policy programs for spinoffs are motivated by concerns that there is too little 'entrepreneurial thinking' (BMBF, 2006: 3) in the day-to-day German research world and that the use of scientific knowledge suffers from an absence of an environment conducive to entrepreneurship. Yet

Andreas Knie is at the Social Science Research Center Berlin, Reichpietschufer 50, 10785 Berlin, Germany. Martin Lengwiler is at the Research Center for Social and Economic History, University of Zurich, Raemistrasse 64, 8001 Zurich, Switzerland. Email: martin.lengwiler@fsw.uzh.ch. for all the rhetoric about the significance of spinoffs, their absolute number in Germany is quite low. In general, approximately 250,000 new companies are added annually to the trade registry. In contrast, the number of spin-offs from universities and research centers averages well below 1000, less than 1\% of all start-ups (Egeln et al., 2002; Potthast and Lengwiler, 2005).

Why are spin-offs such favorites when objectively, there are so few of them? The conventional explanation presents spin-offs as crucial factors in an early stage of the technological innovation process. Compared to other companies, spin-offs are indeed research intensive and account for a high number of patents and licenses (Egeln et al., 2002: 36-41). Since the 1980s, spin-offs have played an important role for the growth of industries, especially those in the fields of information technology and biotechnology (OwenSmith and Powell, 2003). Although derived from historical precedent, today this thesis is based on a rather uncertain prognosis. It takes the measurable number of spin-offs as an indicator of the anticipated, hoped for, but almost immeasurable process of economic and technological innovation (Hemphill, 2005: 476477). Whether present-day spin-offs will really turn out to be the expected motors of innovation will only be certain retrospectively.

This fundamental paradox in the assessment of spin-offs leaves much space for symbolic gestures in 
Andreas Knie is a Professor of Sociology at the Technical University Berlin. He is also a senior researcher at the Social Science Research Center Berlin (Wissenschaftszentrum Berlin (WZB)) and a managing director of the spin-off company InnoZ. Together with Dagmar Simon he is founder of the Project Group Science Policy at the WZB; he is also coordinator of the European Project 'Production of Knowledge Revisited: The Impact of Academic Spin-Offs on Public Research Performance in Europe' (PROKNOW) funded by the European Commission. His research is on the relationship between science and public policy in an era of new modes of knowledge production.

Martin Lengwiler is Assistant Professor for Modern History at the University of Zurich and appointed professor at the University of Basle, Switzerland. He is a founder member of the Project Group Science Policy at the Social Science Research Center Berlin. His research is on the European history of the 19th and 20th century, combining approaches from the history of science with perspectives from cultural and social history. His most recent publication is: Participatory approaches in science and technology: historical origins and current practices in critical perspective (introduction) (Science, Technology, and Human Values, 2008, 33, 186200).

science and research policy. Indeed, as argued in this paper, the history of spin-off policies since the 1960s shows that the anticipated innovation process did not occur in most cases. To account for the persistent financial support of spin-off activities in research policies, we suggest an alternative thesis. We argue that the actual function of spin-offs in research policy lies less in their hard-and-fast number or their direct economic impacts than in their symbolic meaning providing legitimacy for academic institutions and funding agencies in controversial public debates about science and technological policies. Empirically, this paper focuses on the exemplary case of Germany and its recent science-andresearch-policy debates about technology transfers in general and spin-offs in particular. To situate the debates about spin-offs within the larger picture of technology transfer activities and science and research policies, we take a partly historical approach by investigating the emergence of the spin-off issue since the 1960s. In the first section, we legitimate the choice of Germany as a case study and outline the basic structure of the German research system. We then focus on the different stages of technology transfer policies and debates about spin-off activities since the 1960s, placing the strategies in science and research policy in their respective historical context. Different sorts of material are used, including published sources, mainly government papers and academic publications that have appeared since the early 1960s and have dealt with the issues of technology transfer and spin-off activities. We also review recent research in the history and sociology of science examining the recent history of scienceindustry relations in postwar Germany, notably the publications from the research program on the history of institutions conducting big science in Germany (for a survey, see Ritter, 1992).
Theoretically, the paper takes up recent debates about the relation between scientific and political actors in science policy. The topic's popularity ties directly into some of the fundamental problems of science and research policy (Elzinga and Jamison, 1995: 572- 575; Gibbons, 1999). Few other fields of policy are deemed so important to guaranteeing a country's competitiveness, yet in no other area are the possibilities for direct influence through government policy so limited (Braun and Guston, 2003: 306). In principle, the reasons for those fundamental problems of science and research policy have to do with the paradoxes of technology transfer: a phenomenon that is manifested in Germany in an exemplary way. The scientific community needs public funding, but it also needs rights protecting it from interference by politicians or the public, whether in the process of elaborating knowledge gained from reflection or in the generation of applied and product-related knowledge. Science operates in a selfreferential mode because the orientation, grounding, and validation of academic work come primarily through the disciplines, the professional communities that scientists regard as the only source of recognition for 'good' science. In dealing with science, which works by the principle of open-ended results, one cannot just substantively define goals and outputs in the same way as in other policy fields. Instead, academia and government depend on mutual cooperation, on what has been called a "fragile contract" (Guston and Keniston, 1994: 2-4): "Government promises to fund the basic science that peer reviewers find most worthy of support, and scientists promise that research will be performed well and honestly and will provide a steady stream of discoveries that can be translated into new products, medicines, or weapons.” (Guston and Keniston, 1994: 2).

These conditions base government policy on the principle of delegation. Policy-makers 'delegate' to the scientific community the delivery of the desired outcomes, which it then markets autonomously in its own name and on its own account. The direct quality control known in labor market and employment policy, for example, is not applicable in the area of science policy. The classical instruments for goal definition and measurement of policy success or failure lie outside the jurisdiction of government policy, though policy-makers are also made responsible for the results. This 'paradox' (Braun, 2003: 319) means that government policy is compelled to find surrogate performance- and success-related indicators that can legitimate the success of science and research policy. The principle of delegation rules out both direct influence on research topics and the imposition of quality standards on scientific work as instruments of control. David Guston and Dietmar Braun have suggested analyzing the complex relations between policy-makers and scientists by adopting the principal-agent theory to problems in research policy. They expanded the principalagency approach to a triadic relationship between 
policy-makers, funding agencies (or research councils), and scientists, sometimes complemented by a fourth party: the users (Guston, 1996; Braun and Guston, 2003: 304-307). In this sense, the debates about quality standards and assessment instruments can be interpreted as a negotiation process between the principal (politics) and the agent (science) about the use of public funding: a difficult and complex process because it involves intermediate agents such as funding agencies or research councils. The basic tension in the relation between science and politics focuses on the legitimacy of assessing the quality of scientific endeavors. Scientists themselves have a clear understanding of what 'good science' is. In particular, peer-reviewed essays published in international journals are regarded in all academic disciplines as a seal of quality. There are many other criteria, but all of them are based on procedural principles that ultimately guarantee the relevant professional community a monopoly on the evaluation of the results (Simon and Knie, 2007). For policymakers though, the instruments for controlling and assessing science and research policy have to lie elsewhere. In this situation, technology transfer is virtually predestined for measuring the utility of science and research in a publicly convincing manner. Spin-offs occupy a special place in the repertoire of technology transfer because they are empirically observable and measurable. They promise a high practical value for society. Spin-offs are seen as highly innovative and job-creating organizations that are able to adapt flexibly to a changing environment. They thus represent a privileged vehicle for national policy-makers. They are an ideal social and economic measure of the practical value that science and research policies have (OECD, 2001).

\section{Between control and autonomy: science policy in Germany}

Why take Germany as a case study? One reason is that science and research policy in Germany is similar to that in other important nations yet also distinct in critical respects. Like the United States, France, Great Britain, and other comparable states, Germany has a highly elaborate publicly funded science system consisting of universities, other institutions of higher education, several pillars of research

\section{Technology transfer is virtually predestined for measuring the utility of science and research in a publicly convincing manner}

organizations outside the university system (mainly in the field of big science), and a rich tradition of government contract research (Ressortforschung). Another similarity is that academic self-organization is constitutionally protected in Germany and that academics are considered to be a well-organized lobby. And as in other western nations since the 1960s, the German research system has been increasingly marked by the emergence of big-science institutions and large research centers (Hohn and Schimank, 1990; Stamm, 1981). Against this background, Germany offers a typical picture of the problems confronting science and research policies in a delegated system, such as those based on the principal-agent situation mentioned above.

The characteristics of the German case only exacerbate these policy problems. For example, the structures of the research system in Germany are far less centralized than those in France and Britain. The difference is due partly to the tradition of German federalism. The responsibilities in science policy are shared by the German federal government and the Länder, or states (Bentele, 1979). This tradition stretches back to the Second Empire of the late 19th and early 20th centuries but was reinforced after World War II by Allied reconstruction policy. With the decentralization of the political system after 1945, education policy and the university system became a matter for the Länder alone. Government research funding also came solely under Länder management. Thus, research centers formerly run under the aegis of the centralized state, such as the Max Planck Society for the Advancement of Science (or its predecessor, the Kaiser Wilhelm Society) and the Deutsche Forschungsgemeinschaft (the major German foundation for research funding), were now totally funded from the budgets of the Länder (Böttger, 1993: 30-41; Hohn and Schimank, 1990: 102-127; Stamm, 1981: 55-116). The second reason for the decentralized, multipolar structure of the German research system is the split between the universities and the big-science research centers outside the university system that constitute the socalled 'extra-university' research sector. Today, the extra-university research organizations, the Max Planck Society, the Fraunhofer Society, and the Arbeitsgemeinschaft der Großforschungseinrichtungen (the association of big-science centers, since 1970 called the Helmholtz Society), are about as large as the whole university system but remain largely independent of the universities. This arrangement resembles France's division between the universities and the research centers of the Centre National de la Recherche Scientifique (CNRS), but is completely different from the British and the American systems, with their important research universities (Hohn and Schimank, 1990).

In German science and research policy, the comparatively weak central government therefore stands opposite an array of firmly rooted, well-organized, decentralized scientific institutions and Länder 
governments. Recent research has therefore used the concept of 'governance' (the opposite of 'control') to account for the difficulties of political decisionmaking in this field. The concept of governance is taken to mean all coexisting ways of collectively regulating social matters, ranging from the institutional self-regulation of civil society and various forms of collaboration between government and private actors to sovereign action taken by government authorities. Different modes of coordination such as competition, hierarchy, negotiation, and the market exist alongside or in interaction with each other (for an overview, see Jansen, 2007). This conceptual approach enables us to describe the complex structures in which intentional action takes place, but without predetermining the relationship between the objects and subjects of government control. The analytical and practical challenge for government policy, given the prevailing principle of delegation, is to recognize the potential contributions each mode can make and to combine them in a way that offers perspectives on shaping the substance of that policy (Jansen, 2007: 212).

However, these various modes of coordination may also function simultaneously, possibly resulting in unintended policy effects. The universities, for instance, cannot determine either the products of their teaching and research or their pay scales, much less their management personnel (except for a few cases which have recently been permitted) without conferring with the government. On the other hand, the government is prevented from influencing the delivery of results, so its only remaining practical substitute for policy consists in the processes of negotiation and coordination that have become so typical of the scientific community. In reality, not only are scientific evaluations being organized in the universities and the extra-university research centers, but business-management type instruments of quality control are being introduced as well (Münch, 2007).

In summary, the core identifiable problem of science policy is that the government only has indirect leverage over it. Government actors delegate the definition of program development, content, and quality control to the scientific community and try to assert control through delineation of the general framework. This principle of delegation is part of the previously mentioned fragile contract that demands utmost communication, understanding, and coordination from both sides and that, if it is to continue

\section{The core identifiable problem of science policy is that the government only has indirect leverage over it}

functioning, always compels the government to rely on publicly credible surrogate indicators. "The researcher will in the long term strive to achieve a position of highest possible organizational autonomy and lowest possible strategic interdependences.” (Kurek et al., 2007: 512). Spin-offs play a crucial role in that context because government policy and the scientific community alike use them as strategic elements to stabilize the contract (Knie et al., 2008).

\section{Transfer models of German research policy since the 1960s}

A preliminary remark on the concept of 'spin-off': it was not until the 1980s that the word spin-off acquired its present meaning of a new enterprise hived off from an existing company or a public research institution. In the 1960s and 1970s, spin-off meant, in general, the process by which technological know-how and products generated by government research diffuse into the areas of industrial application in the private sector. In the 1970s, this dynamic came to be known in the OECD countries as 'technology transfer'. It is in this context of the 1960s and 1970 s and their changing policies of technology transfer that the notion of spin-offs as used today has been shaped. Thus historically, the concepts of spinoff and technology transfer were closely related (Bräunling and Harmsen, 1976: 78-80).

The direction of German research policy in the early 1960s was deeply influenced by debates about the presumed 'technology gap' between the European and American research systems. In those years the lag represented the key motive for West Germany to establish federal research funding (Bräunling and Harmsen, 1976: 69-70; Mutert, 2000: 32-34, 40-43). The discourse erupted over empirical statistics collected and published by the OECD, which had been created in 1961. The comparative data on the technological development in the western industrialized nations consistently seemed to document that the European states were structurally trailing the United States and Japan. The need to catch up was particularly strong in largescale and cutting-edge technologies in nuclear energy, aeronautics and space, and microelectronics. The OECD's significance in the propagation of the notion that a gap existed is evident partly from the fact that its proponents were nicknamed, in the

\section{German research policy in the early 1960s was deeply influenced by debates about the presumed 'technology gap'}


jargon of science policy at the time, as 'gapologists' (Böttger, 1993: 119-121; Bräunling and Harmsen, 1976: 72). It is from this policy background that the term 'spin-off' emerged. The word was originally formulated in the context of American research and technology policy of the 1960s and quickly spread to Europe, often as 'spill-over' or 'fall-out' (Bräunling and Harmsen, 1976: 88).

The decisive impetus for the legitimation of West German research policy thus repeatedly came from the United States. The American debates about spinoffs arose from the massive preponderance of military research in research funding immediately after World War II. That dominance drew increasing criticism, for $90 \%$ of all USA federal research expenditures in 1953 went on military projects. Critics especially objected to the lack of social and economic utility accruing from military research. Such reproach achieved a change in the justification for investment in military research. The federal authorities started to stress that the knowledge and products generated by military research would also benefit the civilian sector: as spin-offs of the military technologies (Bräunling and Harmsen, 1976: 79-80.). This process was initially understood to mean automatic diffusion that did not need to be monitored or promoted further.

At the same time, the West German authorities also raised high public expectations of a spin-off effect, copying the American spin-off debate about the legitimation of developing large science institutions. The Federal German Ministry of Scientific Research (BMwF), which followed from the Federal Ministry of Nuclear Affairs in 1962 and was responsible for overseeing the country's institutions of big science, legitimated the immense investment by pointing to the diffusion effect of technological innovations (Böttger, 1993: 38-41; Stamm, 1981: 155-171). The rationale for the costs of space research, for example, was spelled out in the first issue of the Bundesbericht Forschung (Federal Research Report), a publication initiated by the research ministry in 1965 and published at regular intervals ever since. ${ }^{1}$ The argument was that the "technical experiences with missiles, space vehicles, and ground installations (...) are of great economic importance because they involve ultramodern technical experiences that can be successfully exploited outside space-flight technology as well (...)." (BMwF, 1965: 121; our translation). Analogously, the BMwF legitimated the expenditures for defense research by holding out hope for a technological thrust. In the ministry's words: "Crucial technical knowledge and discoveries of the past 30 years have their origin in defense research, including radar, control technologies, information and computer technology, the use of nuclear energy, aeronautics and space, [and] business and systems research" (BMwF, 1965: 61; our translation).

This idea of legitimating research costs by pointing to passive spin-offs met with broad political and social acceptance, enjoying support in the 1960s from governments led by the center-right parties (the Christian Democrats (CDU) and members of the Bavarian sister party, the Christian Social Union (CSU)). After 1966 this backing continued under a grand coalition between the CDU and the center-left party, the Social Democrats (SPD) (Bräunling and Harmsen, 1976: 80-81). The business associations and the relevant scientific institutions also embraced it, a hardly surprising response because the government institutes and their industrial partners alike profited from the model of big science and its considerable funding. Thus, public and private parties involved in big science were interested in broad popular acceptance of this line of research (Bräunling and Harmsen, 1976: 81; Mutert, 2000: 193-223).

Even then, the actual impact of assumed spin-offs was very small. In the 1970s, estimates for West Germany rested on the assumption that only about $10 \%$ of the investments in institutions pursuing big science paid-off in economically useful innovation (Bräunling and Harmsen, 1976: 81). A survey of participating industrial enterprises in the 1970s found that the utility of research projects was seen to lie primarily in the marketing area, in the enhanced reputation gained through involvement in prestigious European projects, rather than in the technological know-how that was generated (Bräunling and Harmsen, 1976: 206-207).

\section{Science policy with an interventionist agenda: the planning euphoria around 1970}

The advent of the Grand Coalition in the Federal Republic of Germany (1966-1969) heralded the emergence of a proactive stance on science and research policy. Although support for science and research was still intended to help improve the competitiveness of the national economy, it was also expected to enhance the quality of life (Szöllösi-Janze, 1990: 88-94). In 1968 the reasons for a reorientation of West German federal science policy were laid out by the country's minister of research, Gerhard Stoltenberg. He cited the experience with the economic crisis that had brought the lengthy boom in the economy to an end as of the mid-1960s, preparing the ground for an interventionist concept of the state. Moreover, he emphasized that it was necessary to have a "constant, flexible adaptation of government expenditures (...) given the present economic facts" and that scientific research therefore had to be planned more thoroughly. He also stated that these policies required "completely new forms of close, institutional cooperation between the government, the scientific community, and business, the determination to overcome traditional limitations and mistaken thinking about autonomy” (Stoltenberg, 1968: 93; our translation).

From today's perspective, this passage expresses a remarkable push for active government participation 
in the development of scientific knowledge and a sign of just how fragile the contract between academia and the government actually was in times of crisis. In the 1969 Federal Research Report, it was inferred that "partial collaboration between the government, the scientific community, and business in research planning and funding" was no longer sufficient (BMwF, 1969: 36; our translation). Faced with the insistence of universities and research organizations on the autonomous self-governance of science, the $\mathrm{BMwF}$ subsequently ceased efforts to coordinate and to set priorities within the federal funding programs.

The research ministry reoriented its strategy, making the socioeconomic relevance of research results the pivotal criterion, though that was not operationalized in precise terms. The call sounded by the 1967 Federal Research Report read accordingly: "Research policy must not be guided solely by [the goal of] closing gaps. It must henceforth focus more intensely and more consistently on the tasks upon whose solution the continued development of society and the economy especially depend." (BMwF, 1967: 7; our translation). This new strategy was manifested partly in new funding priorities intended to encourage the development of new key cuttingedge technologies regarded as relevant to the future in areas beyond the classical fields of big science.

The technology-transfer models used up to 1969 were redefined in the rhetoric of the SPD-Liberal coalition that came to power in West Germany thereafter (Szöllösi-Janze, 1990: 78-80). The background of this reorientation in science policy was an increasingly critical attitude toward the first generation of spin-offs, particularly in the United States. Here, skepticism about the purported diffusion effect was already growing in the early 1960s, especially in military research and the NASA space program. In response to the resulting criticism, various research institutions, particularly NASA, decided to pursue the diffusion of technological innovations more intensely than before and start an active policy on spin-offs (Bräunling and Harmsen, 1976: 199-203; NASA, 2002, 3-4). Moreover, spin-off policies gradually shifted beyond institutions of big science. Studies on the effectiveness of enterprising spinoffs, most of them in Boston (Route 128) or the San Francisco Bay area (Palo Alto and Silicon Valley), first appeared in the mid-1960s in the United States and showed that a host of new technology firms had sprung up in the immediate vicinity of universities and research centers (Bräunling and Harmsen, 1976: 85; Berndts and Harmsen, 1985: 21-25; for an early secondary analysis, see Keune and Nathusius, 1977: 17-20). These university-related spin-off companies gave rise to important regional economic centers, such as Silicon Valley around Stanford University (Keune and Nathusius, 1977: 17-20). Because of the regional economic significance of these centers, Great Britain and France began trying to copy this model in the 1960s by launching public funding programs (e.g. Cambridge, Milton Keynes, and Sophia-Antipolis near Antibes) (Keune and Nathusius, 1977:14-15, 65-68). In West Germany, however, such projects were not possible until much later, in the late 1980s.

Responding to a parliamentary question in 1972, the federal government stated that it was abandoning the rather passive approach it had been taking. "The federal government considers it better to channel funding directly to tasks that are socially and economically important and promise technological success than to inflate expectations about the utility of the more or less random byproducts of research (the socalled fallout)" (as cited in Bräunling and Harmsen, 1976: 82; our translation). ${ }^{2}$ This open admission that previous policy had been merely symbolic made it possible to establish the term 'technology transfer' successfully and to legitimate and ensure its longterm extension beyond big science to include practically all areas of research and technology policy. The new policy signaled a shift in the target audience of technology transfer, with small business and academic spin-offs figuring prominently along the way (Bräunling and Harmsen, 1976: 85-92).

\section{Technology transfer as a strategy for legitimating science: the debate about models of active transfer in the 1970 s}

The German federal government's announcement that it wished to rein in the hitherto operative principle of delegation forced the scientific community to respond. Representatives of scientific institutions and defenders of academic self-organization very soon managed to convince government proponents that their interventionist project was impossible. Peter Glotz, a renowned German scientist and science politician, wrote in his autobiography how well organized the academic networks were. The representatives of the important funding institutions succeeded in framing the planned inroads on academic self-government as massive intervention in academic freedom. With a few efficient and informal backroom discussions, they managed to reverse the intended government policies. A central factor was that these meetings were attended by only a handful of men, most of whom belonged to the generation brought up during and immediately after World War II and marked by a specific culture of consensus (Glotz, 2005: 150). Another likely reason that their minds met so quickly was that they came to agree on pragmatic and coordinated forms of governance and created a "complex cooperative system" (Szöllösi-Janze, 1990: 82) of various actors who, above all, practiced informal concertation among themselves from then on. To forge an early understanding on principles and strategies of research policy, the research ministry under Stoltenberg convened the leading figures of this new steering group, which later became known as the 'Holy 
Alliance', for their inaugural meeting as an informal advisory body. It consisted of the presidents from the Conference of University Presidents, the Max Planck Society, the Wissenschaftsrat (German Science Council), and the Deutsche Forschungsgemeinschaft (German Research Foundation). This arrangement reestablished the principle of delegation, making the government dependent once again on surrogate criteria for measuring the success of science policy (Szöllösi-Janze, 1990: 84-88).

In the course of this ultimately successful attempt to defend the freedom of academic self-management and to secure the reciprocal advantages of the contract, the scientific institutions saw themselves increasingly compelled to improve their own public communication of what they were actually doing. To safeguard academic self-management and hence also the principle of delegation in science policy, they began to provide their own evidence of the usefulness of their research. The representatives of the major funding agencies like the German Research Foundation and of the extra-university research organizations had realized that active engagement in the process of planning and implementing the public research programs was a very effective way of bringing in the interests of scientists. A series of research programs thus included advisory boards and working groups, in which the specific interests of scientists were melded with those voiced by the representatives of the federal research ministry. In addition, the research centers of big science started their own information campaigns to inform the general public about the topics and the products of their own expensive research infrastructure (Laudel, 2006; Zuckermann and Merton 1971: 66-100; Daele et al., 1979: 32-34).

As a result, a multitude of new centers and instruments for facilitating technology transfers emerged. In keeping with the federal structure of the West German science system, the process proceeded in a very decentralized and nonuniform manner. The extra-university research organizations (the Max Planck, the Fraunhofer, and the Helmholtz Societies) were the first to create their own offices for technology transfer. The technical universities did so later, with the other universities finally following suit in the 1980s along with the technical colleges (the Fachhochschulen) specialized in a single discipline, such as engineering, architecture, design, art, or business administration (see Rupp, 1976: 92-104).

For years, however, the scientific institutions and the research ministry disagreed on the pace and strategic orientation of transfer policy. As was basically clear to all parties, the logical need for the constantly escalating expenditures for research and development had to be conveyed to the public more effectively than in the past, in order to avoid jeopardizing the rules of the contract between the scientific community and government policy. But whereas the Max Planck Society, for example, actually set about optimizing the economic exploitation of its research results, the big-science research centers in particular were more interested in a symbolic policy (Mutert, 2000: 70-87). As the offices for technology transfer multiplied, the research ministry itself was doing everything possible to keep from losing further ground in the science institutions and to avoid even being excluded from a future role in measures for achieving legitimation.

The confusion wrought by this melee is well apparent in the discussions that Margit Szöllösi-Janze and Susanne Mutert studied with regard to the changing licensing and patent policies in the Helmholtz research centers during the 1960s and 1970s. Although the Helmholtz Society had been exploring ways of expanding the commercial use of technology since the mid-1960s, the research centers and institutes disagreed with each other and with the federal research ministry on how to improve the lackluster patenting and licensing policies. Having the closest industrial links, the Jülich research institutes (the Society for Nuclear Processes and the Jülich Nuclear Research Station) began in 1966 to call for a policy of active exploitation of patents. Until that time, the commercialization of patents followed a decentralized and non-exclusive license policy in which the research centers were themselves responsible for the marketing of their innovations. As the main funding institution, the national government owned the preferential rights for the commercial use of patents. However, the rights were non-exclusive and the research centers could also sign licensing contracts with industrial partners, although again only in a non-exclusive form. Within this non-exclusive and decentralized framework, both potential patent users, the government and the industry, had hardly any incentives for licensing research innovations (Mutert, 2000: 72-73). Since the mid-1960s this policy was increasingly criticized, although with different interests. Some active research centers, such as the Jülich center, demanded a better coordination of the patent policy, the Helmholtz Society claimed a centralization of the transfer activities in its own hands, and the research ministry tried to avoid the misuse of publicly funded research products for private commercial interests. Thus, the research ministry remained skeptical about the arguments of the Jülich center and its close relations to the industry (Mutert, 2000: 73-78). Big science was still the sole area of federal activity in the science system. Eventually in 1967 a poor compromise, on which the Helmholtz Society and the research ministry eventually agreed, resulted. It demonstrated how far the technology transfer debate of the 1970s was already merely a symbolic gesture. The Helmholtz Society started a central patent database through which all big-science centers had to list their annually registered patents. The information in the database was published and provided to interested industrial partners (Mutert, 2000: 73-78; Szöllösi-Janze, 1990: 75-77). As non-exclusive patent law was not changed, the industry's interest in the patent 


\section{5-1978 showed that only one licensing agreement came of the 17,000 published patents in the central database of the Helmholtz Society}

database remained negligible. 1975-1978 showed that only one licensing agreement came of the 17,000 published patents in the central database of the Helmholtz Society. The database merely served to acquire legitimacy and was finally closed in 1988 (Mutert, 2000: 88-89).

The reservations of the Helmholtz Society about actively marketing their intellectual properties and a respective support of spin-offs is further illustrated by the foundation of the Garching Instrumente $\mathrm{GmbH}$, the patent exploitation company of the Max Planck Society, in 1971. Pointedly, this initiative came from exponents of the Helmholtz Society who were unhappy with the society's passive policies of technology transfer. The Institute for Plasmaphysics in particular, which futilely fought for a more active transfer policy within the Helmholtz community, left the Helmholtz Society in 1970 and switched to the Max Planck Society partly because it favored the profit-oriented patent policies of some Max Planck institutes. The Max Planck Society embraced its new member with open arms and took the enlargement as an opportunity to found a new technology transfer office, the Garching Instrumente GmbH. The emergence of Garching was an important institutional step. With it, the Max Planck Society became the first among the extra-university research organizations to have a centralized institution for an active transfer policy (Mutert, 2000: 78-81).

\section{Modest outcomes: anchoring technology transfer in recent federal funding policies}

The necessity of research funding based on the principle of delegation grew steadily in the 1970s, as the funding of big science continued to play a key role within Germany's federal research policy. With the increasing investments in research, the pressure for legitimating the financial expenses by the expected profits of technology transfers was also rising. The institutes and centers of big science were the only recourse the federal government had in science policy to establish focal points in research funding programs without becoming mired in constitutional conflict with the Länder. Meanwhile, the high costs and spectacular fiascos of specific big-science projects, combined with the lacking profits of technology transfers, continually made the funding of big science a target of public criticism. More than one project ended as an investment failure in the 1960s and 1970s, examples being: the vertical take-off airplane; the development of the quick breeder nuclear reactor, the high-temperature reactor, and a gigantic windmill; and the booster rocket program of the European Launcher Development Organisation (Kommission für wirtschaftlichen und sozialen Wandel, 1977: 253-255; Szöllösi-Janze, 1990: 278-279). The few efforts at technology transfer, which were merely symbolic in any case, fizzled without effect (Mutert, 2000: 61-62). Moreover, expansion of the BMFT's budget for institutes of big science, especially for nuclear energy, ceased after 1973 because of recession, and the career paths of young scientists heading to big-science research centers were blocked indefinitely by job cuts (Mutert, 2000: 108-110; Szöllösi-Janze, 1990: 214-215).

Under these conditions both the federal research ministry and the Helmholtz Society sought to stress the economic and social utility of the research investments. When controversy over an active patent and licensing policy failed to be resolved in the 1960 s, the view slowly but surely prevailed that it was necessary to couple science and industry more closely in order to legitimate research policy. The sensational failures demonstrated to both the federal research ministry and the general public that the potential of academic self-government was very limited, at least for research programs with costly technical infrastructure. The big-science institutions lacked all appropriate management qualifications and governance experiences. The conclusion was that academic institutions should receive no new funding for programs of technological innovation without close cooperation with industrial partners (Szöllösi-Janze, 1990: 217-218). Even the BMFT overcame its skepticism of licensing policy based on exclusive guarantees, like the one adopted by the Max Planck Society. As of 1977, the ministry went still further, explicitly recommending the Garching model of the Max Planck Society as exemplary (Mutert, 2000: 84).

A real milestone in the restructuring of the relation between public policy and science was finally reached in 1978 with the so-called two-thirds rule. As an incentive for big-science research centers to exploit the results of their research, this provision at last made it permissible for two-thirds of their additional revenue from the sale of licenses to be reported as profit and retained in their own budgets. In the line-item logic underlying the canons of public budgeting, the licensing revenues until then had the effect of reducing subsidies, leaving the centers with no financial interest in a proactive licensing policy. Being allowed to keep up to two-thirds of those revenues to cover spending on technology transfer henceforth increased the motivation to institutionalize and professionalize transfer activities. Furthermore, exclusive licensing agreements were now allowed within the Helmholtz Society (SzöllösiJanze, 1990: 280-218). 
The debates leading to the new regime show the same camps as the discussions about the patent and licensing policy in the 1960s: the research centers asked for more autonomy when dealing with industry partners, the association of big-science research centers hoped for a centralization, and the research ministry acted against any misappropriation of public funds for commercial profits. The shift from the previous regime to the two-thirds rule was made possible by a combination of factors: the increasing pressure on improving the conditions of technology transfers, which helped to gradually change the attitude of the federal research ministry, but also a centralization process of the association of big-science research centers which led in 1970 to the foundation of the Helmholtz Society (Bräunling and Harmsen, 1976: 90-91; see also: Mutert, 2000: 100-101).

As early as the 1970 s, research centers were now granted entrepreneurial scope to engage in economic activities essential for legitimating research policy directly on their own. After the creation of the Fraunhofer institutes, the research ministry succeeded yet again in firmly tying the need for research utility to the institutional conditions of research work. Basically, the mutual understanding on the problems of legitimating public funding and modern research conditions gradually expanded from the mid-1970s onwards. The federal research ministry realized that visible output of the big-science research centers depended on the ministry's willingness to address the self-interests of the individual research organizations in its policies: something that the Helmholtz Society had long been calling for. Under increasing public pressure for tangible results of the costly investments in big science, the research ministry came to accept the demands of the research centers (Szöllösi-Janze, 1990: 281). The principle of delegation was left untouched, but the informal modes of negotiation led to a substantial change in the rules of scientific work for the first time.

Overall, the two-thirds rule was successful. In the first four years (1978-1982), it brought the bigscience research centers additional revenues of nearly €23 million, mainly profiting the technology transfer offices of the institutes and centers. By 1981 all Helmholtz research centers had a transfer office, or at least a professional transfer officer (Mutert, 2000: 148-149).

\section{Overall, the two-thirds rule was successful. In the first four years (1978-1982), it brought the big-science research centers additional revenues of nearly $€ 23$ million}

The previous disasters of the major science projects and the lack of success with technology transfer had still further impacts (Szöllösi-Janze, 1990: 210-213). Empirical results in the early 1970s, especially from the evaluation research organized by the newly founded Fraunhofer Institute for Systems Technology and Innovation Research, changed the transfer strategies in two regards. First, the primarily technology-oriented transfer approaches of the period were complemented by person-centered funding models. It became apparent that the transfer of new products, processes, and know-how often functioned inadequately for lack of implicit knowledge, whereas the transfer of persons proved to be more positive. The trend toward person-centered transfers no doubt also profited from the funding cuts at the research centers and from the attendant pressure on the workforce to change jobs. At least in the area of big science, many institutes encouraged personnel to move to the business sector, the ulterior motive being that harsher measures to cut personnel could thereby be avoided (Mutert, 2000: 104-107).

The second change in research policy concerned the private-sector target audience of technology transfer. Up to that time it was big industry that profited most from cooperation with public research institutions. The networks between big science and big industry in particular had traditionally been closeknit and effective, not least because of the complex technological tasks with which the industrial partners in big-science research centers were charged. In $1971,80 \%$ of the funding for industrial research within big science programs (mostly aeronautics and space research) went to enterprises with more than 5000 employees (Kommission für wirtschaftlichen und sozialen Wandel, 1977: 252-253, 283-284; for information on the 1980s, see Duisberg, 1983). The small and medium-size enterprises were definitely at a disadvantage in research policy. The structural shift from the large-scale research conducted within the technology programs of the 1950s and 1960s to the funding of new technologies in the 1970s had also entailed a change in industrial cooperation. Many of the new research priorities, such as environmental research, microelectronics, and biotechnology, no longer necessarily required cooperation with big industry. That type of work could be done in collaboration with small and medium-size enterprises (Szöllösi-Janze, 1990: 294).

These two trends in technology transfer (personcenteredness and the orientation to small and medium-size industrial organizations) merged with various new funding programs of the research ministry from the late 1970s onwards. Some of them dated back to that time's coalition between the SPD and the Liberals; others, to the CDU-led government that ruled as of 1982. The programs were designed to provide direct funding for spin-offs from universities and public research institutions as well as from private industry and were intended to strengthen the contact between public research and the sector of 
small and medium-size industry. In the period 19771983, the BMFT began experimenting with a program on 'technology-based business start-ups'. People or organizations interested in founding an enterprise could, with only a modest amount of their own money, apply for public funding covering up to $90 \%$ of the required start-up capital.

By today's standards, these arrangements were very generous. The federal ministry had meanwhile realized that it wasn't enough to promote spin-offs if the number of newly founded enterprises did not eventually increase-as indeed it did not. Moreover, the ministry was still unable to intervene directly in the development of research programs of the big research institutions. It still depended on indirect measures to increase the quality of publicly funded research. In the 1980s and 1990s, the research ministry therefore started to include industry in the incentive systems of its research programs. The problem was that most of the successful start-ups still came from the private sector. For academics at the universities and public research institutions, moving into entrepreneurial science seemed to be associated with a loss of status in the community of scholars, at least in the early 1980s (Mutert, 2000: 116-120; for an example pertaining to mathematics and dataprocessing, see Wiegand, 1994: 250-274). The programs were not completely ineffective, however. By 1984 the big-science research centers were credited with a total of 84 spin-offs funded by the BMFT (for individual examples, see BMFT 1983, Vol. 1: 124-127, 177-183; for the total figures, see Mutert, 2000: 113; see also Berndts and Harmsen, 1985; Heidrich and Klein, 1997: 18-19).

\section{Conclusions}

The question of why the significance of spin-offs has been stressed politically although their actual number has remained so low can now be answered. Spin-offs, like technology transfer at large, are important to the rationale and legitimacy of science and research policy. In other words, spin-offs demonstrate the utility of the federal government's science policy and serve as a response to a multitude of structural problems in science and research policy. In the terms of the principal-agent theory mentioned in the introduction: spin-offs are a way to deal with some of the delegation problems of the relation

\section{Spin-offs, like technology transfer at large, are important to the rationale and legitimacy of science and research policy}

between the principal (namely the state and the government actors in science and research policy), some intermediary actors such as the funding agencies and the research councils, and the agent (the scientists and research institutes; Braun and Guston, 2003: 303). The persistence of the public debate over spinoffs in the past decades has to do with the ambivalence of the phenomenon. Spin-offs can be used by both actors: by the principal to assess the achievements of the agent, measured in the degree of utility of the research output, and by the agent in order to legitimate the research activities by pointing at its commercial potentials. This ambivalence is the main reason why much of the debate about spin-offs suffers from an overdose of rhetorical and symbolic arguments.

Thus, even after more than 40 years of debate about technology transfer, spin-off activities have not lost their edge as a crucial element of the often token endeavors of government authorities and scientific organizations. In the 1960s the research ministry's call for international technology transfer (oriented to American large-scale research) warranted the development of large-scale research by the Federal Republic of Germany and, indirectly, an expansion of the federal government's authority visà-vis the Länder. Since the recession of 1966-1967, discourse about technology transfer has increasingly reflected the attempt to cope with the structural problems of big-science institutions, often by reforming the external relations of the research centers. The structural problems included the transformation of traditional large-scale technologies for developing modern technologies, big industry's dominance over small and medium-size industry in research cooperation, and pressures to cut jobs and costs in research centers. In the 1980s the discussion of transfer concepts in research policy were increasingly marked by economic policies reflecting the doom conveyed by the economic outlooks since the recession of 1973-1974. In addition, technology transfer was presented as an antidote to small business's lack of innovation and as a catalyst of economic transformation in structurally weak regions. In recent years spin-offs have been considered evidence of a generally innovation-friendly research environment (WR, 2007).

However, the low number of academic spin-offs demonstrates that government science policy is limited in its ability to substantiate the utility of research. Thus paradoxically, the persisting significance of spin-offs in science and research policy is not an indicator for diminished tensions between the principal (politics) and the agent (science), rather the opposite. The contract between government and science will remain fragile as long as the cooperation is based on the principle of delegation, as it still is today (though its main supporters are now found in the academic institutions rather than among government authorities as in the 1950s and 1960s). The effectiveness of policy instruments for exerting external 
and indirect influence depends on the academic community's acceptance of the indicators and performance parameters defined by government policy and on their recognition as a guide for scientific work. This acceptance exists only if the academic institutions agree to the given objectives at least for tactical reasons. In particular, the political attempts in the early 1970s to intervene directly in the substance of research and to orient scientific goals to social problems failed because these policies were interpreted by the academic world as an annulment of the delegation contract.

The characteristic features of a community of scholars working autonomously toward open-ended results necessitate methods of greater subtlety in research policy. Recent results of sociological studies on the conditions under which modern modes of knowledge production take place (Knie and Simon, 2006; Leydesdorff and Etzkowitz, 1998; Nowotny et al., 2001) show that the regulations of line-item accounting, which apply to practically all scientific organizations in Germany, are the institutional corset for the academic community's internal orientation. Research, which is organized primarily in an autonomous and self-referential setting, is funded by a budget system that is outright impervious to external stimuli so that scientific work is protected as a 'public good'. In this system, revenues in terms of valuable give-and-take with partners outside the institutional boundaries become an administrative problem and are therefore anticipated and officially avoided from the outset: when the research design is defined. In the world of line-item budgeting, stimuli and incentives that help extend the chain of epistemological value creation beyond one's academic peers through interaction with actors from business and industry and that can be budgeted as revenues are regarded as dangerous adventures.

But if efforts succeed at opening up academia's institutional terrain and making the mutual transfer of knowledge attractive, entrepreneurial initiative can become a legitimate part of scientific practice and can translate more quickly, directly, and diversely into products and enterprises than is presently the case. Scientific quality will also be enhanced by the fact that dialectical interactions between research and application are made possible by various testing and validation authorities. The essential thing is the acceptance of such 'crossovers' within the community of scholars and the acknowledgment of the results as part of good science. Recent findings support the thesis that the new forms of knowledge production are highly receptive to such an arrangement for institutions governed by public law (Bercovitz and Feldmann, 2006; Murray, 2004). Spin-offs would not be token endeavors of technology transfer based on symbolic policy but rather part of a modern approach to the production of science and knowledge, one arising from a reform of science policy.

\section{Notes}

1. Since the creation of the Federal Republic of Germany in 1949, successive portfolios, each with a different title and scope, have been responsible for research, science, technology, education, other matters pertaining to the academic community (e.g. funding and relations with business and industry), or some partial combination of these areas. The names relevant in this paper are the Ministry of Scientific Research (BMwF, 1963-1972), the Ministry of Research and Technology (BMFT, 1972-1994), and the Ministry of Education and Research (BMBF, 1994-present). In this paper we also refer to this government function generically as the research ministry.

2. In the 1960 s and 1970 s the term 'fallout' meant a form of passive spin-off (see Mutert, 2000: 60).

\section{References}

Bentele, Karl-Heinz 1979. Kartellbildung in der allgemeinen Forschungsförderung. Königstein: Anton Hain.

Bercovitz, Janet and Maryann Feldmann 2006. Entrepreneural universities and technology transfer: a conceptual framework for understanding knowledge-based economic development. Journal of Technology Transfer, 31, 175-188.

Berndts, Peter and Dirk-Michael Harmsen 1985. Technologieorientierte Unternehmensgründungen in Zusammenarbeit mit staatlichen Forschungseinrichtungen. Cologne: Verlag TÜV Rheinland.

BMBF (Bundesministerium für Bildung und Forschung) ed. 2006. Die High-Tech Forschungsstrategie der Bundesregierung Berlin/Bonn: BMBF.

BMFT (Bundesministerium für Forschung und Technologie) ed. 1983. Technologie-Transfer aus Forschungseinrichtungen: Bilanz und Perspektiven (Technologie-Transfer, Vol 1). Cologne: BMBF.

BMwF (Bundesminister für wissenschaftliche Forschung) 1965. Bundesbericht Forschung I. Bonn: BMwF

BMwF (Bundesminister für wissenschaftliche Forschung) 1967. Bundesbericht Forschung II. Bonn: BMwF

BMwF (Bundesminister für wissenschaftliche Forschung) 1969. Bundesbericht Forschung III. Bonn: BMwF.

Böttger, Joachim 1993. Forschung für den Mittelstand. Die Geschichte der Arbeitsgemeinschaft industrieller Forschungsvereinigungen "Otto von Guericke" e.V. (AiF) im wirtschaftspolitischen Kontext. Cologne: Deutscher Wirtschaftsdienst.

Braun, Dietmar 2003. Lasting tensions in research policy-making: A delegation problem. Science and Public Policy, 30, 309-321.

Braun, Dietmar and David H Guston 2003. Principal-agent theory and research policy: an introduction. Science and Public Policy, 30, 304-307.

Bräunling, Gerhard and Dirk-Michael Harmsen 1976. Die Förderungsprinzipien und Instrumente der Forschungs- und Technologiepolitik. Göttingen: Schwartz.

Daele, van den, Wolfgang, Wolfgang Krohn and Peter Weingart 1979. Die politische Steuerung der wissenschaftlichen Entwicklung. In Wolfgang van den Daele, Wolfgang Krohn and Peter Weingart, Geplante Forschung, pp. 11-63. Frankfurt: Suhrkamp.

Duisberg, Carl-Heinz 1983. Forschungssubventionen an Großunternehmen: wettbewerbs- und verfassungsrechtliche Probleme der Vergabepraxis. Bielefeld: Gieseking.

Egeln, Jürgen, Sandra Gottschalk and Christian Rammer 2002. Spinoff- Gründungen aus der öffentlichen Forschung in Deutschland. Mannheim: Zentrum für Europaische Wirtschaftsforschung (ZEW-Dokumentation 03-02).

Elzinga, Aant and Andrew Jamison 1995. Changing policy agendas in science and technology. In Sheila Jasanoff et al. (eds), Handbook of Science and Technology, pp. 572-597. Thousand Oaks, CA: Sage.

Gibbons, Michael 1999. The New Production of Knowledge: The Dynamics of Science and Research in Contemporary Societies. London, UK: Sage.

Glotz, Peter 2005. Von Heimat zu Heimat. Berlin: Econ.

Guston, David H 1996. Principal-agent theory and the structure of science policy. Science in Public Policy, 23, 229-240.

Guston, David H and Kenneth Keniston 1994. Introduction. The 
Social Contract for Science. In David H Guston and Kenneth Keniston eds. The Fragile Contract: University Science and the Federal Government, pp. 1-41. Cambridge, MA: MIT Press.

Heidrich, Wolfgang and Thomas Klein 1997. Campus Companies. Innovative Modelle der Zusammenarbeit zwischen Hochschule und Unternehmen. Cologne: Deutscher Instituts-Verlag.

Hemphill, Thomas 2005. National technology entrepreneurship policy: foundation of a network economy. Science and Public Policy, 32, 469-478.

Hohn, Hans-Willy and Uwe Schimank 1990. Konflikte und Gleichgewichte im Forschungssystem. Akteurskonstellationen und Entwicklungspfade in der staatlich finanzierten außeruniversitären Forschung. Frankfurt: Campus.

Jansen, Dorothea ed. 2007. New Form of Governance in Research Organizations, Berlin: Springer.

Keune, Ernst Jürgen and Klaus Nathusius 1977. Technologische Innovation durch Unternehmensgründungen. Eine Literaturanalyse zum Route 128 Phänomen. Cologne: Wison Verlag.

Knie, Andreas and Dagmar Simon 2006. Forschungen im CrossOver Modus. Wissenschaftliche Ausgründungen in neuen Arrangements der Wissensproduktion (discussion paper). Berlin: WZB.

Knie, Andreas, Dagmar Simon, Holger Braun-Thürmann, Heike Jacobsen and Gerd Möll 2008. Entrepreneurial Science? Typen akademischer Ausgründungen. In Peter Weingart, Friedhelm Neidhardt, Renate Mayntz and Ulrich Wengenroth eds., Wissensproduktion und Wissenstransfer (transcript, Bielefeld) (forthcoming).

Kommission für wirtschaftlichen und sozialen Wandel 1977. Endbericht. Göttingen: Schwartz.

Konrad, Kornelia and Bernhard Truffer 2006. The Coupling of Spin-offs and Research Institutions in the Triangle of Policy, Science and Industry. An International Comparison (discussion paper). Berlin: WZB.

Kurek, Kasia, Peter A T M Geurts and Hand E Roosendaal 2007. The research entrepreneur: strategic positioning of the researcher in his societal environment. Science and Public Policy, 34, 501-513.

Larédo, Philippe and Philippe Mustar 2001. Research and Innovation Policies in the New Global Economy. Cheltenham, UK: Edward Elgar.

Leydesdorff, Loet and Henry Etzkowitz 1998. The triple helix of innovation. Science and Public Policy, 25, 358-364.

Laudel, Grit 2006. The art of getting funded: how scientists adapt to their funding conditions. Science and Public Policy, 33, 489-504.

Münch, Richard 2007. Die akademische Elite. Zur Konstruktion von Exzellenz. Frankfurt: Suhrkamp.

Murray, Gordon 2004. The role of academic inventors in entrepreneurial firms: sharing the laboratory life. Research Policy, 33, 643-659.

Mutert, Susanne 2000. Grossforschung zwischen staatlicher Politik und Anwendungsinteresse der Industrie. Frankfurt: Campus.

NASA (National Aeronautics and Space Administration) 2002. Spinoff 2002 (Fourtieth Anniversary Technology Utilization Program). Available at <www.sti.nasa.gov/tto/spinoff2002/ index1.html>, last accessed 28 March 2008.

Nowotny, Helga, Peter Scott and Michael Gibbons 2001. Rethinking Science, Knowledge and the Public in an Age of Uncertainty. Cambridge, UK: Polity.

OECD (2001), STI Review No. 26. Special Issue on Fostering High-tech Spin-offs: A Public Strategy for Innovation. Paris: OECD.

Owen-Smith, Jason and Walter W Powell 2003. The expanding role of university patenting in the life sciences: assessing the importance of experience and connectivity. Research Policy, 32, 695-711.

Potthast, Jörg and Martin Lengwiler 2005. Arrangements der Wissensproduktion: Akademische Ausgründungen zwischen Forschung und Markt. Sozialwissenschaften und Berufspraxis (SuB), 28(2), 214-230.

Ritter, Gerhard A 1992. Grossforschung und Staat in Deutschland. Ein historischer Überblick. Munich: Beck.

Rupp, Erik 1976. Technologietransfer als Instrument staatlicher Innovationsförderung. Anwendung der Ergebnisse staatlicher und staatlich geförderter Forschung und Entwicklung im internationalen Vergleich. Göttingen: Schwartz

Simon, Dagmar and Andreas Knie 2007. Aus Mangel an Beweisen: 'Exzellente' Kriterien in der Wissenschaft? Gegenworte, 17, 27-29.

Stamm, Thomas 1981. Zwischen Staat und Selbstverwaltung: die Deutsche Forschung im Wiederaufbau 1945-1965. Cologne: Verlag Wissenschaft und Politik.

Stoltenberg, Gerhard 1968. Hochschule Wissenschaft Politik. Zwölf Beiträge. Frankfurt: Ullstein

Szöllösi-Janze, Margit 1990. Geschichte der Arbeitsgemeinschaft der Grossforschungseinrichtungen, 1958-1980. Frankfurt: Campus.

Wiegand J 1994. Informatik und Grosssforschung: Geschichte der Gesellschaft für Mathematik und Datenverarbeitung, Frankfurt/Main: Campus.

WR (Wissenschaftsrat) 2007. Empfehlungen zur Interaktion von Wissenschaft und Wirtschaft. Oldenburg: Wissenschaftsrat.

Zuckermann, Harriet and Robert K Merton 1971. Patterns of evaluation in science. Minerva, 9, 66-100. 